\title{
The problem and promise of story
}

\author{
Kathryn Jones \\ Calgary Board of Education \& University of Calgary \\ KEJones@cbe.ab.ca
}

\begin{abstract}
This paper reflects upon taking up stories with high school students that are full of graphic images of war, genocide and ethnic cleansing. Young people today are bombarded with images of human suffering via the media; when teachers take up traumatic stories, they add to an already overwhelming tide. Narrative and critical analysis are woven together to explore students' responses to such stories in Canadian schools in which productivity and performance are often used as indicators of student success. Instead, opportunities and possibilities to teach pedagogies of peace and possibility are imagined.
\end{abstract}

Last year I found myself working with a group of about 35 grade 11 students at a Calgary high school. They'd worked hard all semester, and were eagerly anticipating the presentation of their portfolio projects, some of them because they'd worked so hard, and others because jumping over this hurdle meant that weeks of summer freedom stretched before them. The students had read a variety of texts of their choice over the course of the semester exploring what it might look like to live a "good" life, and about the nature and consequences of some of the many social, political, economic and environmental constraints human beings face in the world today. Two students, Ariel and Nicole, had volunteered to present first. On that late spring afternoon, sitting in near darkness, they had a captive audience.

Ariel's presentation was a response to the Canadian novel Three Day Road by Joseph Boyden (2005). He began with a poem composed in response to Xavier's experiences as a Cree sniper in the trenches of the First World War. This character was traumatized by his war experiences, and in particular the transformation of his childhood friend Elijah from a hopeful and proud young man into a deranged, blood thirsty and vengeful killer who collected and carried with him human scalps as trophies. The presentation shifted, thereafter, to an exploration of Xavier's morphine addiction, and ultimately the Post Traumatic Stress Disorder he experienced upon returning to Canada after the war. Ariel told us about the increasing incidence of this condition in North America today, particularly in adolescents. It dawned on me, as I attempted to process the statistics he presented, that if his sources were accurate, at least one of the young people I was surrounded by at that moment could have been silently suffering from this condition. As I looked around the room I wondered who that person might be and what might have traumatized him or her?

Cultural and Pedagogical Inquiry, 2015, 7(1), pp. 72-83

ISSN 1916-3460 @ 2015 University of Alberta

http://ejournals.library.ualberta.ca/index.php/cpi/index 
When Ariel finished speaking we applauded. I asked a couple of questions, but observing that the class wasn't going to participate in a discussion, we moved on to Nicole's presentation. We were, as ever, running out of time. She was responding to the novel The Cellist of Sarajevo by Steven Galloway (2008), and began her presentation with the haunting melody of an adagio played on a cello. Nicole's presentation, of more than fifteen minutes, consisted of a series of black and white photographic images of the genocide that took place in Sarajevo in the 1990s. I imagine she'd found them via a straightforward "Google" search for images related to "Sarajevo and genocide" and had put them together as a slide show for us to view. My eyes shifted between the 35 or more sixteen year old people I was surrounded by as image after image of burnt out buildings, piles of dead bodies and devastation on an unimaginable scale beating on the screen before us. The beautiful music and Nicole's thoughtful narration were jarringly juxtaposed with profound images of destruction. The class sat silently, absorbing these images, and remained speechless when the presentation concluded.

As I sat watching my students I was struck by the matter of fact way they seemed to respond to being bombarded by images of genocide, war and human suffering. Their faces remained expressionless through both presentations. It seemed normal that we were doing this, natural even. It was this sense of the everyday and the ordinary in the face of genocide and trauma that struck me. I wondered as I sat there in the hushed aftermath of these presentations, listening to the whir of the projector from the centre of the room, whether reading traumatic literature, and such ready and prolific exposure to graphic images of inhumanity, could actually instigate a traumatic response in a student? Was it possible that by encouraging my students to read and respond to such difficult texts I could be inducing so much stress and pain that they ended up with Post Traumatic Stress Disorder? Could sitting silently by in the face of suffering on such an unimaginable scale actually contribute to what might be described as a broader social "numbing" in the face of destruction? Were my students silent because they didn't care, or had they detached and distanced themselves in order to cope? What was going on?

The bell rang... ${ }^{i}$

What do teachers hope for when they expose students to stories of human suffering, war and trauma that are devastating? Perhaps being devastated is the goal. Authorized reading lists in Alberta (and no doubt elsewhere) are filled to the brim with stories of suffering (see http://education.alberta.ca/teachers/program/english/resources/ela-list.aspx). Reading traumatic literature has become so commonplace, exposure to images of loss, decay and disintegration expected by students, and thus the horror of suffering may no longer be as horrific as it once was, or as it ought, perhaps, to be. Should teachers encourage students to read stories of a world that $i s$ dark and disturbing? Sheltering students from these stories in an age of instantaneous access to so much information may be impossible. I have always believed in the importance of exposure to 
what human beings are capable of, both the wonderful and the atrocious. However as a teacher I read stories with the hope of inspiring students to participate and invest themselves in the world, not in order to destroy hope and invite retreat into narcissism, self-interest and even posttraumatic stress. The reasons why teachers read stories of suffering with their students and what happens in the process (if anything does) are worthy of consideration.

There is an argument to be made for the richness and interpretability of every day experiences. David Loy (1993) sheds light on the value of focusing on interpreting a single experience when he invokes the image of a piece of paper (this one, which my text marks) as "nothing less than the entire universe" (p. 482). His discussion of the fact that "not one thing" is "not here- time, space, the earth, the rain, the minerals in the soil, the sunshine, the cloud, the river, the heat," points to the possibility that "everything in the universe is in [the classroom experience recounted in my opening]." If, as David Loy states, "each thing in the universe is both a mirror, reflecting all, and an image, reflected by all," (p. 483) then this discussion explores what this classroom experience might mirror and reflect about pedagogical spaces, about the images human beings are bombarded by in this technological and digital epoch and about the relationships between the young and their elders that might develop in classrooms.

Stuart and Kyle came into the classroom late after lunch. They'd been across the street at the local coffee shop and, as was often the case, had lost track of time. It was not unusual for students in this class to bustle in late, in a state of excitement and agitation, ready to debate any and every topic. This day was no different. Despite the fact that I was attempting to explain something to the class, Stuart trundled, beaming, across the room in front of me, balancing his hot drink in one hand and his overflowing backpack over his shoulder. He thrust something into my hands. "This," he said, "is what school does to young people. This is why reading in school sucks." Accustomed, as I was, to such interruptions I thanked Stuart for the gift without glancing at it, laid it on my desk and continued on with the lesson. Later, when I began to unpack the stacks of paper on my desk that had accumulated that day, I stumbled across the comic Stuart had been so enthusiastic about sharing with me. This is what I saw:

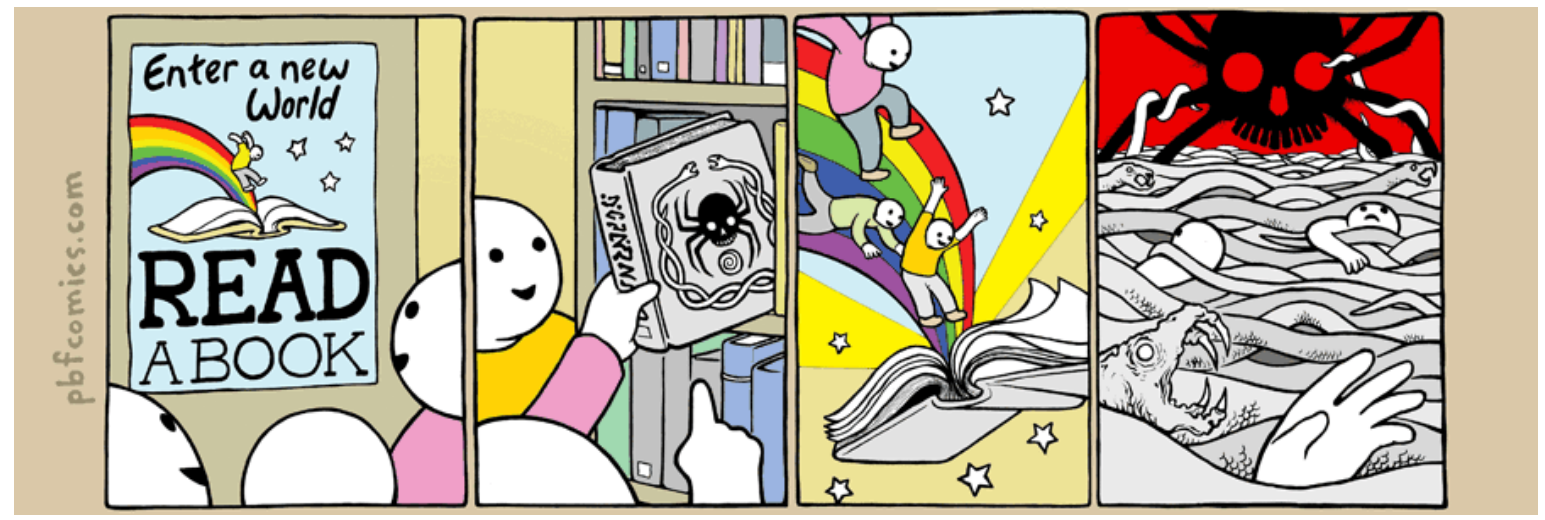

Book World (Gurewitch, 2001-2008) 
Each of the frames pose interesting, provocative and difficult questions about what the purpose of reading is, about the experience of being an English Language Arts teacher working with young people in this time, and about the dangers of what can or might happen when exploring difficult texts. In the face of what Claudia Eppert (2007), citing Humphries, describes as the "unspecified loss that characterize[s] much of mainstream Western literature and art in the last two centuries as works of interminable mourning," (p. 96) I am reminded of the capacity of literature to "wound" and the "dynamics of melancholia and mourning" (p. 97) that are in play when readers/viewers witness traumatic events vicariously through stories. I wonder how teachers might cultivate a sense of response-ability in/with the young in the face of such stories, instead of enabling them to drown in feelings of guilt, powerlessness, apathy, paralysis and devastation?

The young people I teach find themselves in increasingly technology driven and information-saturated societies/schools, attempting to survive what David Loy (2009) describes as an "information tsunami" (p. 80). Thomas Eriksen (2001) suggests many people in the world today are literally pickled in information. When I invite my students to contemplate literature, I add to what is already an enormous and overwhelming tide. In this context, it is vital that teachers think deeply about what stories students are exposed to, why these choices are made and what happens (as Hans-Georg Gadamer, 2004, suggests) beyond my (pedagogical) wanting and doing in the English Language Arts classroom.

The threat of world destruction may feel more familiar today than any other time in history. Images of civil unrest, warfare, natural disaster, global warming, pollution of the land, air and sea, radiation poisoning and species extinction bombard those who turn on the television, $\log$ onto the Internet, or browse the newspaper. That is, of course, if one is privileged enough not to be facing such horrors in the flesh. Andy Fisher (2002) discusses a resulting estrangement from the natural world and embedded-ness in (and need to articulate) discourses of "loss" today. He explains that our "bodies understand language" and that it is through language that life is carried forward (p. 62). Coming to terms with, and working to cultivate a discourse of loss, means witnessing the "destruction, impoverishment, attenuation and extinction of our experience in modern times" and the frightening "waning of affect" that is occurring in an "age of bland numbness" and "neurotically split [personalities]" (p. 83). This is perhaps the origin of the 
difficulty of living in language today, and studying stories wherein readers/viewers are faced with the impoverishment of the world, a facing that is often difficult and painful.

We confront the possibility, as Andy Fisher (2002) acknowledges, at any time of "sliding into a state in which most people are too distressed, are not in any kind of shape, to ever turn their attention to the betterment of society" (p. 180). People turn to language and to the stories told in and through language in order to interpret them/ourselves, and perhaps find "collective ways to bear our pain and suffering, to strengthen ourselves, so that we can stop negating life and instead get back to it" (p. 190). Don Domanski (2006) suggests that art and poetry, the subjects of the English Language Arts, awaken us to the "aliveness of things" and help to keep a "sacred fire alive amid the destructiveness and greed that is an ever-present darkness we must navigate daily" (p. 8). The worlds entered into and existing in language and the stories that hold this language, cultivate a sense of amazement. One of the difficulties is that this amazement "also demands that we see the darkness inherent in everything, that we see the destructiveness implicit in creation and its attending grief' (p. 7). The stories human beings create, share and hold are expressions of living in and of the world.

While literature provides what Dennis Sumara (2002) describes as "opportunities for identifications", it does not necessarily guarantee that "meaningful" relationships to "people or their ideas will occur" (p. 10). The cultivation of these relationships depends, to a large extent, on the stories one is exposed to (or not), and the skills of interpretation that are cultivated. But the very possibility of developing literary commonplaces, or spaces wherein young people can have access to others outside of their own life experiences is significant. Reading stories together in schools can provide a space for the cultivation of literary commonplaces, locations wherein individuals can explore the human condition together, as it is, has been and might be (Sumara, $1996 \& 2002)$.

Throughout history human beings have sought out and (re)created stories that frighten and repulse. Why are so many people drawn to stories that are terrifying? Why return to such stories again and again? Ben Okri (1997) suggests that one of the reasons why human beings have sought out such stories throughout history is because they may have been "more terrifying than the darkness [we] feared, or the unknown that [we] cowered from, or the storms that threatened to tear off the roof of the sky, or [our] destinies- the greatest terror of them all" (p. 
37). In other words, human beings seek out and create stories that depict suffering because they make an individual's own suffering and frailty, by contrast, more bearable. Stories reconnect individuals to "the great sea of human destiny, human suffering and human transcendence" (p. $38)$.

Perhaps veracious consumption and repetition of tragic stories enables individuals to experience the "lived" world as less devastating? There is often a felt distance between a story world and everyday life. While many stories are inspired by "real" life tragic events, experiencing suffering vicariously through narrative provides individuals with a critical distance from which to contemplate and cultivate resistance to real suffering. Richard Kearney (2003) suggests that works of mourning might be "so many thought experiments which may help us to see connections between the ethical aspects of human conduct and fortune/misfortune" (p. 101). In other words, he argues that works of mourning invite readers to resist "the alienation of evil, that is, to move from a position of mute helplessness to acts of revolt and self-renewal" (p. 104). The mere possibility of this resistance occurring is a reason to engage in the study of stories with young people in schools.

One of the most painful (and vital) experiences of reading literature is that good and worthwhile stories tend to pose questions rather than answer them. In a culture obsessed with answers, resolution and finality, the work of engaging with texts that provoke questions rather than close them down or eliminate them is difficult. This may be one of the reasons why young people struggle to enjoy the English Language Arts. Many people are so used to speaking, as Martin Heidegger points out (cited by Maxine Greene, 1988), in “calculative terms," but stories do not speak this kind of language. Stories invite people to take notice of the way the world has been and is, in order to question it, and to begin thinking about ways in which it might be otherwise. Maxine Greene (1988) suggests that in an age of science, reason, procedure and method it is "particularly significant to move the young into conversations about the good and just life" so that images of despair can become a "summons" to act, rather than a way in which individuals can simply fall into joining forces with the pestilence" (p. 479). Can teachers find ways to think about and work with stories in order to "summon" their students, call them into question, without shutting them down, turning them off or letting them turn away? Can teachers, themselves, remain open and responsive in the face of stories of human suffering? 
As a teacher, I invite students to read and interpret stories not only so that they can contemplate existing worlds; I want them to imagine new worlds. Aidan Chambers (1996) says that reading offers "images for us to think with and a means of creating and re-creating the very essence of our individual and corporate lives" (p. 18). Reading, talking about, questioning and imagining stories with students can make space for what Maxine Greene (1988) describes as "dreaming children, wondering children, caring children- competent, yes, but aware of the deceptiveness of the signs, singing when they can and fending off the darkness on a Blakean 'echoing green'” (p. 480). I want students to encounter human suffering through stories in my classroom, and I want them to question, to challenge and to imagine how suffering in the world might be alleviated.

The frenzy we find ourselves in presently, obsessed by what we are doing in educational spaces, might well be encouraged by the fact that we live in a capitalist epoch. In the context of what David Smith (2009) describes as this "defining grand narrative of our time, global capitalism" ( $p$ 97), it is not surprising that we tend to think compulsively about production and being productive in schools. In an age in which accumulation is equated with success and progress it is not uncommon for teachers to fall victim to thinking about what they do to students more than about how they are with them. Education systems teeter on the edge of falling prey to capitalist discourses in which education "becomes a site of management of differences, no longer a place where enduring, indeed common, human values are deliberated and decided upon as courses of action" (David Smith, 2009, p. 97). Uncritically embracing the discourses of differentiating, personalization, constructivism and student-centered learning can lead to pedagogical positions in which teachers stand helplessly by as statistics about the incidence of post-traumatic stress disorder amongst North American teens and images of genocide flashed upon a screen in front of classes and overwhelm (or appeared not to whelm my students at all!).

Inviting students to "fall" into stories in a classroom and being present if and when they do so is a difficult task. The structure of the school system, one in which teachers are too often expected (or encouraged) to remain distant from their students at the front of the classroom, to hide their own human vulnerability from their students and to do something to them rather than participate in something with them does not invite deep affective, bodily and critical responses in 
public school classrooms very often. Such occurrences are even more rare when policy and legislation lead the public to believe that education can be a detached and impartial enterprise.

Some days I feel as though my students and I are sinking in a tide of information. Thomas Eriksen (2001) describes contemporary ("Western" industrialized) societies as characterized by "acceleration, growing complexity, a sense of uprootedness and fast technological change" (p. 56). I imagine my students, who are more "plugged in" than I am, must be even more sensitive to this reality than I. As a parent and teacher I worry about the world young people inherit. Individuals are more exposed than ever before to images (stories) of suffering in an information saturated and media dominated culture: overwhelming tidal surges, earth shattering quakes, governments firing on innocent civilians, civil strife, radiation poisoning threatening the globe, Canadian bombs "flashing" on video images uploaded to the internet as they descend on military targets in far off lands. Is this a war? Whose war? Is this the apocalypse? What is going on? If the mainstream media has become, as David Loy (2008) states, a "collective nervous system" (p. 101) then who are we, where are we, and where might we go from here?

David Loy (2010) poetically describes "Samsara, this world of suffering and craving and delusion, [as] a pounding surf that seizes and slams us against the rocks beneath" (p. 45). I wonder, alongside scholars like him, whether salvation is "reaching the beach and relaxing on the sand," or "learning how to surf, which plays with the energy of the waves"? I wonder, as a teacher, if "instead of drowning in the sea we can learn to dance with it" (p. 45)? How might communities of educators imagine (and maybe even enliven) schools that nurture and awaken the young, rather than detaching them from the world/others and putting them to sleep?

How can I carry on as a teacher in a public school classroom? How can I continue to reorient myself as I work with students in these unsettled and unsettling times? Can I experience my classrooms as a common space that is peaceful, gentle and deliberately oriented to/for life? Dennis Sumara (1996) suggests that the "conditions of reading" (p. 239) that teachers cultivate with students influence the relationships they have with them and with their understanding of the texts they explore. While many of the events/processes that impact pedagogical spaces are beyond the control of teachers, I am beginning to imagine that a teacher's classroom might be, or at the very least aspire to be, otherwise. 
Instead of thinking about what teachers $d o$ with/to the young in their classrooms, they might start to think more about how they are with their students. What are teachers rushing towards (and in the process silencing) when they imagine English Language Arts classrooms as spaces in which all that is done is "consume" (story after story) and "produce" (project after project)? How can teachers slow down, pay more attention, focus on listening? Thomas Eriksen (2001) describes the new forms of scarcity we confront in today's classrooms: "slow time, security, predictability, belonging, stable personal identity, coherence and understanding, cumulative, linear, organic growth, real experiences (which are neither ironic nor mediated by mass media)" (p. 30). These scarcities contribute to the atmosphere of dread and impossibility depicted in the final frame of the comic strip. It is these new scarcities that teachers might begin to work against, even if (and perhaps because) the surrounding culture tends to view them as an inevitable outcome of "progress" and "development".

Hannah Arent (1954) puts the precarious and difficult pedagogical situation into words beautifully when she says:

Basically, we are always educating for a world that is or is becoming out of joint, for this is the basic human situation, in which the world is created by mortal hands to serve mortals for a limited time as home. Because the world is made by mortals it wears out; and because it continually changes its inhabitants run the risk of becoming as mortal as they are. To preserve the world against the mortality of its creators and inhabitants it must be constantly set right anew. The problem is to educate in such a way that a setting right anew actually remains possible, even though it can, of course, never be assured. Our hope always hangs on the new which every generation brings. But precisely because we base our hope only on this, we destroy everything if we so try to control the new that we, the old, can dictate how it will look. Exactly for the sake of what is new and revolutionary in every child, education must be conservative; it must preserve this newness and introduce it as a new thing into an old world, which, however revolutionary its actions may be, is always, from the standpoint of the next generation, superannuated and close to destruction (p. 192).

Her words remind me that the job of a teacher is to preserve newness rather than overcome or overpower it. The future is simultaneously within and outside of our control. It is precisely this sense of so much being "out of our control" that makes teaching such pressing and important work. If the old stories of schooling are beginning to wear out, can teachers begin to think about 
how we might create the conditions that make a "setting right anew" of our schools and the lives of our children actually possible?

I wonder...

how the shape of schools and the work teachers do might shift if schools were imagined as places in which teachers dwell together with the young, instead of spaces in which teachers do things to/for them? The use of the word "dwell" is deliberate here and pays homage to scholars like Ted Aoki (Pinar and Irwin, 2005) who have invited me to consider what it means to dwell. Can teachers consciously build and work to sustain classroom spaces that are nourishing and supportive and healthy for human habitation? Can teachers make space for wondering, give individuals opportunities to "voice" their diverse life experiences and focus on what all people have in common? If the goal is for students to feel "at home" in school, and by extension, at home in the world they read about in stories, English Language Arts teachers might keep in mind that the classroom cannot be a place where teachers merely "get through" the curriculum and work towards the test. The classroom can be a space in which individuals attend to, become troubled about and converse with one another, in and over the world we inhabit together. 


\section{References}

Alberta Education (2005). Authorized resource list. Retrieved from http://education.alberta.ca/teachers/program/english/resources/ela-list.aspx

Arendt, H. (1952). Between past and future: Eight exercises in political thought. New York: The Viking Press Inc.

Boyden, J. (2005). Three Day Road. Toronto: Penguin Group.

Domanski, D. (2006). Poetry and the sacred. Nanaimo, BC: Institute for Coastal Research.

Eppert, C. (2007). Fear, (educational) fictions of character, and Buddhist insights for an artsbased witnessing curriculum. In C. Eppert and H. Wang. (Eds.), Cross-cultural studies in curriculum: Eastern thought, educational insights (pp. 55-108) New York: Lawrence Erlbaum Associates.

Eriksen, T. H. (2001). The tyranny of the moment: Fast and slow time in the information age. London: Pluto Press.

Fisher, A. (2002). Radical ecopsychology: Psychology in the service of life. Albany: State University of New York Press.

Gadamer, H. G. (2004). Truth and method ( $2^{\text {nd }}$ ed.). New York: Continuum Publishing Group.

Galloway, S. (2008). The cellist of Sarajevo. Toronto: Vintage Canada.

Greene, M. (1988). What are the language arts for? Language Arts, 65(5), 474-480.

Gurewitch, N. (2001-2008). Book world. Retrieved from The Perry Bible Fellowship: http://pbfcomics.com/130/

Kearney, R. (2003). Strangers, gods and monsters: Interpreting otherness. New York: Routledge.

Jones, K. (2012). Unpublished M.A. thesis: Encountering Storied Worlds. University of Calgary.

Loy, D. (2009). Awareness bound and unbound: Buddhist essays. Albany: State University of New York Press. 
Loy, D. (1993). Indra's postmodern net. In Philosophy East and West, 43(3), 481-510.

Loy, D. (2008). Money, sex, war, karma: Notes for a Buddhist revolution. Boston: Wisdom Publications.

Loy, D. R. (2010). The world is made of stories. Boston: Wisdom Publications.

Okri, B. (1997). A way of being free. London: Phoenix House.

Pinar, W. and Irwin, R. (Eds.). (2005). Curriculum in a New Key: The collected works of Ted T. Aoki. Mahwah, N.J.: Lawrence Erlbaum and Associates.

Smith, D. (2009). Critical notice: Engaging Peter McLaren in the New Marxism in education. Interchange, 40(1), 93-117.

Sumara, D. (1996). Private readings in public: Schooling the literary imagination. New York: Peter Lang.

Sumara, D. (2002). Why reading literature in school still matters: Imagination, interpretation, insight. Mahwah: Lawrence Erlbaum Associates.

\footnotetext{
${ }^{\mathrm{i}}$ All italicized excerpts are memories of the author and recount experiences, wonderings and questions from her time as a high school English Language Arts teacher. These stories are included in her M.A. thesis, Encountering Storied Worlds (Jones, 2012).
} 